\title{
Hyperthermia Combined with Chemotherapy - Biological Rationale, Clinical Application, and Treatment Results
}

\author{
R. Issels \\ GSF - Forschungszentrum für Umwelt und Gesundheit, Institut für Molekulare Immunologie und \\ Klinikum Großhadern, Medizinische Klinik III
}

\section{Key Words}

Hyperthermia · Thermochemotherapy · Phase II/III studies, clinical results

\section{Summary}

There is substantial evidence from preclinical data that the antitumor cytotoxicity of selected chemotherapeutic agents either alone or combined with radiation can be enhanced by appropriate heat exposure $\left(40-44^{\circ} \mathrm{C}\right)$ of cells or tumor tissues. Based upon these results the integration of hyperthermia as an additional treatment modality, given simultaneously with systemic chemotherapy or in combination with radiochemotherapy, is currently tested at the clinic. Regional hyperthermia combined with chemotherapy or radiochemotherapy showed impressive results (phase II studies) at clinical relevant temperatures in locally advanced tumors of different entities in terms of objective response rate, local tumor control and relapse-free survival. Clinical protocols of well-designed phase III trials on combined treatment modalities integrating hyperthermia are rather limited but for some tumors confirm its clinical benefit. In general, the clinical approach to use hyperthermia has gained much more interest within in the field of medical oncology. One of the major reason is the substantial technical improvements made with the available commercial equipment for local or regional heating, especially in case of deep-seated lesions or systemic heating. Further testing of the potential of hyperthermia combined with chemotherapy or radiochemotherapy in prospective randomized trials are warranted. At this time, hyperthermia as an adjunct to conventional treatment strategies is recommended in the setting of clinical protocols. The results of prospective trials should answer the question for which types of local advanced or metastatic tumors hyperthermia becomes standard as part of a multimodal treatment strategy.

\section{Schlüsselwörter}

Hyperthermie · Thermochemotherapie · Phase-II/III-Studien, klinische Ergebnisse

\section{Zusammenfassung}

Die Ergebnisse der präklinischen Forschung zeigen, daß die therapeutische Effektivität ausgewählter Zytostatika sowie deren Kombination mit Bestrahlung unter hyperthermen Bedingungen $\left(40-44^{\circ} \mathrm{C}\right)$ in Tumorzellen und Tumorgeweben gesteigert wird. Auf dieser thermobiologischen Grundlage wird derzeit im Bereich der Klinik die Integration einer Hyperthermie als zusätzliche therapeutische Möglichkeit mit simultan applizierter systemischer Chemotherapie oder in Kombination mit Radiochemotherapie untersucht. Im Rahmen von Phase-II-Studien wurde für die Thermochemotherapie und Radiochemotherapie bei klinisch relevanten Temperaturen in lokal fortgeschrittenen Tumoren verschiedener Entitäten beeindruckende Resultate erzielt, wobei die objektive Ansprechrate, die lokale Tumorkontrolle und das rezidivfreie Überleben die wesentlichen Endpunkte darstellten. Klinische Ergebnisse von prospektiv randomisierten Phase-III-Studien unter Einbeziehung der Hyperthermie in multimodale Therapieansätze liegen nur vereinzelt vor, zeigen aber für einige Tumorentitäten einen deutlichen Vorteil zugunsten der Hyperthermie. Insgesamt ist im Bereich der internistischen Onkologie ein zunehmendes klinisches Interesse an der Hyperthermie festzustellen. Einer der wesentlichen Gründe ist der technische Fortschritt im Bereich kommerziell erhältlicher, ausgereifter Systeme zur lokalen bzw. regionalen Hyperthermie besonders für tiefliegende Tumoren oder Ganzkörperhyperthermie. Eine weitere Überprüfung der Hyperthermie kombiniert mit systemischer Chemotherapie oder Radiochemotherapie in prospektiven Phase-III-Studien ist dringend notwendig. Zum jetzigen Zeitpunkt sollte die klinische Anwendung der Hyperthermie als zusätzliche Maßnahme zu konventionellen Behandlungsstrategien im Rahmen klinischer Protokolle erfolgen. Die Ergebnisse derartiger Studien werden die Antwort geben, für welche Art von lokal fortgeschrittenen oder metastasierten Tumorentitäten eine Hyperthermiebehandlung als Teil eines multimodalen Vorgehens einen klinischen Standard darstellt.

\begin{tabular}{ll}
\hline KARGER & @ 1999 S. Karger GmbH, Freiburg \\
Fax +49 7614520714 & Accessible online at: \\
$\begin{array}{l}\text { E-mail kargergmbh@aol.com } \\
\text { www.karger.com }\end{array}$ & http://BioMedNet.com/karger
\end{tabular}

Prof. Dr. Rolf Issels

Klinikum Großhadern, Medizinische Klinik III

Marchioninistraße, D-81377 München (Germany)

Tel. $+49897095-4768$, Fax -8876

E-mail Issels@med3.med.uni-muenchen.de 


\section{Introduction}

The clinical application of hyperthermia with an increase of tissue temperatures (range $40-44{ }^{\circ} \mathrm{C}$ ) has been integrated into multimodal anticancer strategies. This innovative treatment approach within the field of medical oncology is based on the evidence that hyperthermia enhances not only the radiosensitivity of tumors, but also the therapeutic effects of anticancer drugs, even in drug-resistant cells. Beside direct cytotoxicity of heat and thermal enhancement of drug efficacy, hyperthermia might be potentially useful to modulate the immune response against heated tumor cells at moderate temperatures by inducing the expression of heat shock proteins (HSP). Profound research has produced a scientific basis for the simultaneous application of hyperthermia in combination with ionizing radiation and/or systemic chemotherapy. The rational for regional hyperthermia (RHT) is based upon direct heat cytotoxicity and thermal enhancement of radio- and/or chemosensitivity within not well-perfused areas of the individual tumor. These areas usually are hypoxic and drug supply is limited but reaching highly effective temperatures $\left(42-43{ }^{\circ} \mathrm{C}\right)$ due to low convection of heat. Whole-body hyperthermia (WBH) is usually applied simultaneously with systemic chemotherapy to patients having metastatic disease with the intention of thermal enhancement of drug sensitivity. This method is used not to target the heating field to individual tumors but to increase the core temperature of the patient's body (range $40-41.8^{\circ} \mathrm{C}$ ). At present the combination of RHT and chemotherapy or radiochemotherapy is administered within clinical protocols (phase II/III) in order to improve local tumor control and relapse-free survival in patients with high-risk, locally advanced tumors of different entities. WBH is currently tested in phase I/II protocols to evaluate feasibility and toxicity and to determine further the efficacy in patients with metastatic disease refractory to conventional chemotherapy.

\section{Thermobiology}

Cell survival studies have shown that heat-induced cytotoxicity is dependent on temperature and time of exposure. For an isoeffect induced in a specific cell type or tissue by heating for different times at different temperatures, a strong time-temperature relationship exists, showing a large increase of cytotoxicity at higher temperatures $\left(42.5-45^{\circ} \mathrm{C}\right)$. Cells exposed to more moderate temperatures $\left(<42.5^{\circ} \mathrm{C}\right)$ are resistant to continuous heat exposure $(2-4 \mathrm{~h})$, which means they become thermotolerant [1]. Thermotolerance can also be induced at higher temperatures but its development requires time intervals of approximately $6-12 \mathrm{~h}$ at $37^{\circ} \mathrm{C}$ before second heat exposure. The cellular status of thermotolerance is reversible and is greatly diminished about $48-72 \mathrm{~h}$ after the triggering heat dose has been applied. Thermosensitivity itself, but also the development of thermotolerance are influenced by various environmental parameters as $\mathrm{pH}$, oxygen, nutritional supply, but also by the proliferative status of cells [2,3]. The target for heat cytotoxicity is considered to be at the level of cellular proteins [4]. Whether the major interaction of hyperthermia and cellular proteins occurs at the level of the structure of membranes, cytoplasm, cytoskeleton or nucleus, still is an open question. One of the most exciting fields of thermobiology is our better understanding of the so-called 'thermal stress response' that relates to the early activation of heat shock genes encoding the preferential synthesis of HSP [5]. Under normal conditions and in response to stress, HSP are implicated in protein-protein interactions such as folding, translocation and prevention of inappropriate protein aggregation [6]. An emerging field is the role of HSP in the stimulation fo the immune response against cancer in which members of different HSP families (e.g. HSP70, HSP90-related glycoprotein gp96) are involved [7]. When purified from cells, it has been shown that they are associated with a broad range of peptides derived from that particular cell, such that the HSP chaperon the antigenic repertoire of the cells from which they are purified [8]. Immunotherapy of mice with preexisting cancers using HSP preparations derived from autologous cancer resulted in retarded progression of the primary cancer, a reduced metastatic load, and a prolongation of the life-span [9]. The role of HSP may be also interesting in that the heat-inducible HSP70 expressed on the cell surface of certain tumor cells acts as positive recognition signal for natural killer (NK) cells [10]. Therefore, beside direct cell cytotoxicity, hyperthermia has the additional potential for use in immunotherapy in clinical applications.

\section{Heat and Chemotherapy Interaction}

By combining heat exposure with anticancer drugs, a cooperative effect can be observed, dependent on the specific chemotherapeutic agent. In general, selected cytotoxic drugs showed an enhanced inhibition of clonogenic cell growth in vitro at higher temperatures. The magnitude of the thermal enhancement ratio (TER), which is defined as the ratio of the dose of a drug causing a given level of cell death in the presence of absence of hyperthermia, depends on the treatment temperature, time of exposure and drug concentration. Excellent reviews on the interaction of hyperthermia with a wide range of anticancer agents in models employing cells in tissue culture or rodent tumors have been presented by Hahn [11], Dahl [12] and Urano [13]. Despite the complexity of the underlying mechanisms for the observed thermal enhancement, the phenotype of interaction can be classified into 3 categories using isobologram analysis of in vitro data [14]: 1 . independent; 2 . additive; 3. synergistic. The term noninteractive (= independent) describes a situation in which hyperthermia and the individual drug appear to act by independent mechanisms. For some agents, the slope of the survival curve changes smoothly with continuously increasing temperature, meaning that hyperthermia results in the additivity of damage by increasing the cytotoxic mechanism (=additive). A third group of drugs shows distinct threshold effects: little or no sensitization at low temperatures, but marked sensitization occurring at $42{ }^{\circ} \mathrm{C}$ or higher (= synergistic). The classification for selected anticancer drugs whose modes of action fall into one of these categories is shown in table 1 .

Antimetabolites (e.g. 5-fluorouracil, methotrexate) do not seem to be the optimal candidates for combination with hyper- 
thermia because the combined effect of heat and drug exposure upon cell survival is equal with the effect of each individual treatment alone (=independent action). In addition, both taxanes (paclitaxel and docetaxel) did not show any significant thermal enhancement of cytotoxicity using different time intervals between the administration of taxanes and hyperthermia. The efficacy of alkylating agents (e.g. cyclophosphamide, ifosfamide and melphalan) but also of the nitrosoureas (e.g. BCNU) was enhanced by hyperthermia, both in vitro and in vivo. Maximal effects occurred when the agents were scheduled simultaneously with hyperthermia in vitro (endpoint: clonogenic survival) and immediately before hyperthermia in vivo (endpoint: tumor growth delay). In vivo the TER was the same for temperatures between $40.5-42.5^{\circ} \mathrm{C}$, with only a slight increase at higher temperatures of $42.5-44.5^{\circ} \mathrm{C}$. The importance of appropriate timing and sequencing for the evaluation of heat and drug interaction was recently shown for gemcitabine (=2',2'-difluorodesocycytidine). Simultaneous application led to decreased cytotoxicity, whereas an interval of $24 \mathrm{~h}$ between $\mathrm{dFdCyd}$ and hyperthermia led to an enhanced cell killing [15]. For cisplatin (CCDP) and analogues (e.g. carboplatin) a potentiating effect of hyperthermia on cytotoxicity has been demonstrated already at relatively low temperatures of $40.5^{\circ} \mathrm{C}$. Overcoming chemoresistance has been extensively studied within the past, especially using CDDP-resistant cells [16]. In regard to the potential benefit that drug-resistant cells can be recruited for effective therapy by combining chemotherapy with hyperthermia, it was important to show that chemoresistance against several anticancer drugs (e.g. mitomycin $\mathrm{C}$, anthracyclines, BCNU, melphalan) including CDDP could be reversed at least partially by the addition of heat [17]. The effect of thermotolerance and its interference with drug sensitivity of cells is still controversially discussed. However, hyperthermia did not induce cellular p-glycoprotein expression [18], and heat sensitivity of human leukemia clones displaying multidrug resistance was not altered [19]. In conclusion, there is substantial evidence from preclinical data that the antitumoral cytotoxicity of selected chemotherapeutic agents can be enhanced by appropriate heat exposure to cells or tumor tissues.

\section{Clinical Application}

First, clinical hyperthermia can be divided into two almost separate domains: WBH versus RHT. The clinical application of heat can be induced by electromagnetic field technique, ultrasound, or perfusion methods. Lately, noninvasive WBH can be administered with an Aquatherm radiant heat device (Cancer Research Institute, New York, NY, USA), achieving systemic temperatures up to $41.8^{\circ} \mathrm{C}$ [20]. At present noninvasive RHT is most commonly performed using single microwave or ultrasound applicators for superficial hyperthermia and arrays of multiple applicators for deep heating [21]. Preferential heating of different tumor regions is achieved by the lower convection of heat from relatively poorly vascularized areas of tumors compared to their surrounding tissues. During hyperthermia treatments the measurement of the actual temperature distribution in the tumor or immediately adjacent tissue is crucial to the clinical evaluation of the quality of RHT
Table 1. Interaction between hyperthermia and anticancer drugs

\begin{tabular}{lll}
\hline Independent & Additive & Synergistic \\
\hline 5-Fluorouracil & doxorubicin & $\begin{array}{l}\text { cisplatin } \\
\text { carboplatin } \\
\text { mitoxantrone }\end{array}$ \\
Actinomycin D & cyclophosphamide & bleomycin \\
Cytarabine & ifosfamide & \\
Taxanes & melphalan & \\
& BCNU & \\
& gemcitabine & \\
\hline
\end{tabular}

[22]. So far, noninvasive methods for temperature measurements in deep-seated tissues are under investigation [23]. From temperature measurements acquired as temperature versus time and temperature versus depth plots, time-averaged temperatures can be calculated at each site monitored. In addition, the time-averaged temperatures above 20,50 and $90 \%$ of the monitored points (reported in terms of $\mathrm{T}_{20}, \mathrm{~T}_{50}$, and $\mathrm{T}_{90}$ ) allow comparison of different RHT treatments in clinical protocols with regard to the quality of heating [24]. More recently, the clinical application of the thermal isoeffect dose (TID) concept has been applied in retrospective analysis of clinical data to guide future clinical studies in which different treatment protocols for different times at different temperatures are converted into equivalent minutes at $43{ }^{\circ} \mathrm{C}\left(\mathrm{EM}_{43}\right)$ [25].

\section{Regional Hyperthermia Combined with Radiation}

Within the past, the most often performed treatment modality involving hyperthermia was its local or regional application with radiation. Now substantial clinical data exist, demonstrating for the treatment of locally advanced superficial tumors of different entities the improved efficacy and relative lack of normal tissue toxicity of combined radiation and hyperthermia treatments as compared to radiation therapy alone [26]. In addition to the results of numerous phase II studies, more recently the results of European phase III randomized multicenter trials became available. For example, in superficial tumors, an advantage of the combined treatment was shown for recurrent or metastatic melanoma [27] and recurrent breast cancer [28]. In melanomas there was an increase in complete response (CR) or 35-62\% with an 2-year local control rate of 28 versus $46 \%$. The overall 5-year survival rate was $19 \%$, but $38 \%$ of the patients for whom all known disease was controlled, survived 5 years. The cooperative study of the Medical Research Council (MRC, UK) and the Princess Margaret Hospital (Ontario, Canada) demonstrated in recurrent breast cancer an increase in CR of $41-59 \%$ with a 2-year control rate from 20 to $50 \%$, but no statistical difference in overall survival.

\section{Regional Hyperthermia Combined with Chemotherapy}

In the last few years radiation therapists start to accept RHT as an useful adjunct to their modality, motivated largely by 
the results of these studies. Completed clinical protocols on the combination of RHT and chemotherapy are rather limited, but this approach has now gained much more interest within the field of medical oncology. One of the main reasons are the substantial technical improvements made in available commercial equipment for local or regional heating especially for deep-seated lesions and for systemic heating. Another reason is related to the more general acceptance of using multimodal strategies in the treatment of locally advanced cancers in order to obtain optimal local control and to prevent distant metastases. The advanced stages (e.g. T3/4 N1/2) or tumors in unfavorable anatomic locations often prevent primary resection with adequate margins, and the toxicity of radiotherapy limits the use of potentially therapeutic doses. Therefore, based on the benefits of heat-induced enhancement of drugefficacy, the integration of RHT as an additional treatment modality given simultaneously with systemic chemotherapy is currently used in the clinic.

RHT given as an adjunct to systemic chemotherapy has been proven feasible with promising results in phase II trials. In table 2 results are given of several selected studies which have been extended to well-designed phase III trials already started, mainly in Europe. The most relevant aspects of these trials and further applications of thermochemotherapy for different tumor types will be discussed below.

\section{Stomach and Pancreatic Cancer}

Multi-institutional studies on clinical RHT combined with chemotherapy of stomach and pancreatic cancers have been performed in Japan using an 8-MHz-radiofrequency heating device (Thermotron RF8, Yamamoto Co., Osaka, Japan). This system most commonly used for hyperthermia in Japan achieves temperatures within the range of $40-43{ }^{\circ} \mathrm{C}$ in deepseated tumors [29]. A total of 33 patients with stomach cancer ( 29 of them stage IV) and of 22 patients with pancreatic cancer (stage III/IV) received RHT twice weekly combined with mitomycin $\mathrm{C}$ and 5-fluorouracil [30]. Primary tumor response was 39\% (3 CR/10 PR, partial response) and 36\% (3 CR/5 PR), respectively. In addition, objective complaints (e.g. abdominal pain, ascites, passage disturbance, nausea, vomiting) were improved in $66 \%$ of all cases. Although follow-up was limited, among pancreatic cancers 2 patients survived disease-free longer than 30 months and 4 patients were still alive with no regrowth of tumors. These results and also the promising results reported by Shibamato et al. [31] using thermoradiotherapy in nonresectable pancreatic cancer warrant further clinical investigation.

\section{Soft-Tissue Sarcomas and Bone Tumors}

First results were obtained from a phase II study comprising 38 adult patients mainly with soft-tissue sarcomas [32]. These patients had relapsed after prior surgery and radiation and had not responded to previously given chemotherapy alone. The local response rate was $37 \%$. A drug combination of ifosfamide and etoposide (VP 16) has been used combined with RHT as second-line treatment. Beside long-term tumor control in some of the patients, the analysis of tumor temperatures (e.g. $\mathrm{T}_{20}, \mathrm{~T}_{50}, \mathrm{~T}_{90}$ ) achieved with the $\mathrm{BSD}$ system showed significant higher temperature parameters in responders versus non- responders, respectively. These results were confirmed in an extended trial recruiting 65 patients with chemopretreated sarcomas [33]. The consecutive phase II protocol (RHT-91) was designed as a neoadjuvant study where the EIA regimen (etoposide + ifosfamide + adriamycin) was given to 59 patients with high-risk soft-tissue sarcomas (size $>8 \mathrm{~cm}$, grade II/III, extracompartimental) for 4 cycles prior to surgical resection. After first initial analysis showing no severe toxicity or unexpected treatment side effects [34], the evaluation of clinical and pathohistological response was $47 \%$. At present, 29 patients are alive and the median follow-up of all patients is more than 3.5 years. The estimated rate of the 5-year overall survival is $46 \%$ [35]. Further, the EORTC Soft Tissue And Bone Sarcoma Group (STBSG) is testing this multimodal concept as a first-line treatment of high-risk soft-tissue sarcomas in adults in a multicenter prospective randomized phase III trial (EORTC 62961 / ESHO RHT-95) as an intergroup study with the European Society of Hyperthermic Oncology (ESHO). Patients meeting all of the eligibility criteria at first presentation (tumor size $\geq 5 \mathrm{~cm}$, grade II or III, extracompartimental) or in addition after inadequate surgery (resections with microscopic/macroscopic residual tumor) will receive neoadjuvant chemotherapy either combined with or without RHT. WBH achieved by reinfusion of extracorporeal heated blood combined with ifosfamide and carboplatin (CBDCA) showed $6 \mathrm{PR}$ in 19 patients with metastatic disease [36]. In a consecutive phase II study the ICE regimen (ifosfamide + carboplatin + etoposide) was given. In 12 sarcoma patients with distance disease, 7 partial responses were observed [37]. Noninvasive WBH achieved with an Aquatherm radiant heat device has been combined with carboplatin in patients with refractory cancers [38]. It is noteworthy that WBH did not affect the pharmacokinetics of carboplatin in that trial. Also, in repeated pair courses, there was no significant difference in the myelosuppression caused by carboplatin with or without WBH. More recently, the application of melphalan and WBH at $41.8^{\circ} \mathrm{C}$ for $60 \mathrm{~min}$ was well tolerated and the clinical results served as the basis to further elucidate the potential role of $\mathrm{WBH}$ as and adjunct to systemic chemotherapy in advanced cancer patients [39].

\section{Pediatric Cancers}

The application of regional hyperthermia as part of combined modality therapy in pediatric patients, especially with tumors that failed to respond to standard regimen, has been proven feasible with several drug combinations. A multicenter study of the German Society of Pediatric Oncology and Hematology $(\mathrm{GPOH})$ recruited 34 patients (mean age 11 years) mainly with deep-seated advanced soft-tissue sarcomas and Ewing tumors. Among 25 patients with locally advanced tumors, 12 patients of this group achieved no evidence of disease (NED), including 7 patients with CR [40]. Follow-up of these patients showed long-term tumor control ranging from 7 to 64 months. RHT in combination with cisplatin-based systemic chemotherapy in recurrent of refractory extracranial nontesticular germ cell tumors of children and adolescents was found to induce objective tumor response in $70 \%$ of patients.

In comparison to a matched cohort, the probability of eventfree survival was shown to be superior for these patients [41]. 
Table 2. Hyperthermia combined with chemotherapy

\begin{tabular}{|c|c|c|c|c|c|c|}
\hline Authors/Reference & Study & Entity & $\begin{array}{l}\text { Number } \\
\text { of patients }\end{array}$ & Hyperthermia & Chemotherapy & Results \\
\hline $\begin{array}{c}\text { Kakehi et al. } \\
1990[30]\end{array}$ & phase II & $\begin{array}{l}\text { stomach cancer } \\
\text { pancreatic cancer }\end{array}$ & $\begin{array}{l}33 \\
22\end{array}$ & $\begin{array}{l}\text { RHT/Thermotron } \\
8 \mathrm{MHz}\end{array}$ & $\begin{array}{l}\text { mitomycin }+5 \mathrm{FU} \\
\text { mitomycin }+5 \mathrm{FU}\end{array}$ & $\begin{array}{l}3 \mathrm{CR}+10 \mathrm{PR}(39 \%) \\
3 \mathrm{CR}+5 \mathrm{PR}(36 \%)\end{array}$ \\
\hline $\begin{array}{l}\text { Issels et al. } \\
1990[32]\end{array}$ & $\begin{array}{l}\text { phase II (RHT 86) } \\
\text { follow-up }\end{array}$ & $\begin{array}{l}\text { sarcomas (pretreated with } \\
\text { chemotherapy) }\end{array}$ & 38 & $\begin{array}{l}\text { RHT/BSD } 1000 \\
60-110 \mathrm{MHz}\end{array}$ & VP $16+$ IFO & $6 \mathrm{pCR}+4 \mathrm{PR}+4 \mathrm{FHR}(37 \%)$ \\
\hline $1991[33]$ & & $\begin{array}{l}\text { sarcomas (pretreated with } \\
\text { chemotherapy) }\end{array}$ & 65 & $\begin{array}{l}\text { RHT/BSD } 1000 \\
60-110 \mathrm{MHz}\end{array}$ & VP $16+$ IFO & $9 \mathrm{pCR}+4 \mathrm{PR}+8 \mathrm{FHR}(32 \%)$ \\
\hline $1998[35]$ & $\begin{array}{l}\text { phase II (RHT 91) } \\
\text { phase III } \\
\text { (EORTC 62961) }\end{array}$ & $\begin{array}{l}\text { high-risk soft-tissue sarcomas } \\
\text { high-risk soft-tissue sarcomas }\end{array}$ & 44 & $\begin{array}{l}\text { RHT/BSD } 2000 \\
80-110 \mathrm{MHz} \\
\text { RHT/BSD } 2000 \\
80-110 \mathrm{MHz}\end{array}$ & $\begin{array}{l}\text { VP } 16+\text { IFO + ADR } \\
(=\text { EIA }) \\
\text { EIA } \pm \text { RHT } \\
\text { (randomized) }\end{array}$ & $\begin{array}{l}1 \mathrm{CR} / 6 \mathrm{pCR}+8 \mathrm{PR}+13 \mathrm{MR} \\
(47 \%) \text { OS: } 46 \% \\
(12 / 98)\end{array}$ \\
\hline $\begin{array}{l}\text { Eggermont et al., } \\
1996[52]\end{array}$ & phase II & soft-tissue sarcomas & 55 & ILP & $\mathrm{TNF}+\mathrm{IFN}+\mathrm{L}-\mathrm{PAM}$ & 10 CR/35 PR (87\%) \\
\hline $\begin{array}{l}\text { Wiedemann et al., } \\
1994 \text { [36] }\end{array}$ & phase I/II & $\begin{array}{l}\text { sarcomas teratomas } \\
\text { (metastatic) }\end{array}$ & 19 & $\mathrm{WBH}$ & $\mathrm{IFO}+\mathrm{CBDCA}$ & $6 \mathrm{PR}(32 \%)$ \\
\hline $\begin{array}{l}\text { Wiedemann et al., } \\
1996[37]\end{array}$ & phase II & sarcomas (metastatic) & 12 & WBH & $\begin{array}{l}\mathrm{IFO}+\mathrm{CBDCA}+ \\
\mathrm{VP} 16\end{array}$ & 7 PR (58\%) \\
\hline $\begin{array}{l}\text { Robins et al., } \\
1997[39]\end{array}$ & phase I & $\begin{array}{l}\text { refractory cancers } \\
\text { (advanced or metastatic) }\end{array}$ & 16 & WBH/Aquatherm & $\begin{array}{l}\text { L-PAM } \\
\text { (dose-escalation) }\end{array}$ & $1 \mathrm{CR} / 2 \mathrm{PR}(19 \%)$ \\
\hline $\begin{array}{l}\text { Romanowski et al., } \\
1993 \text { [40] }\end{array}$ & phase II & pediatric sarcomas & 34 & $\begin{array}{l}\text { RHT/BSD } 2000 \\
80-110 \mathrm{MHz}\end{array}$ & $\begin{array}{l}\mathrm{VP} 16+\mathrm{IFO}+ \\
\text { CBDCA }\end{array}$ & $\begin{array}{l}12 \mathrm{NED} \text { ('best response')/7 CR } \\
\text { (duration: 7-64 months) }\end{array}$ \\
\hline $\begin{array}{l}\text { Wessalowski et al., } \\
1998 \text { [41] }\end{array}$ & phase II & $\begin{array}{l}\text { pediatric non-testicular } \\
\text { germ cell tumors }\end{array}$ & 10 & $\begin{array}{l}\text { RHT/BSD } 2000 \\
80-110 \mathrm{MHz}\end{array}$ & $\begin{array}{l}\text { CDDP + VP } 16+ \\
\text { IFO (= PEI) }\end{array}$ & $\begin{array}{l}5 \mathrm{CR}+2 \mathrm{PR}(70 \%) 6 \text { patients } \\
\text { alive without evidence of } \\
\text { tumor (10-33 months) }\end{array}$ \\
\hline $\begin{array}{l}\text { Rietbroek et al., } \\
1997[42]\end{array}$ & phase II & $\begin{array}{l}\text { cervical cancer } \\
\text { (recurrences) }\end{array}$ & 23 & $\begin{array}{l}\text { RHT/array system } \\
70 \mathrm{MHz}\end{array}$ & CDDP (weekly) & $2 \mathrm{pCR} / 1 \mathrm{CR}+9 \mathrm{PR}(52 \%)$ \\
\hline $\begin{array}{l}\text { Schilthuis et al., } \\
1998\end{array}$ & $\begin{array}{l}\text { phase III } \\
\text { (ESHO 97-1) }\end{array}$ & $\begin{array}{l}\text { cervical cancer } \\
\text { (recurrences) }\end{array}$ & 5 & $\begin{array}{l}\text { RHT/array system } \\
70 \mathrm{MHz}\end{array}$ & $\begin{array}{l}\mathrm{CDDP} \pm \mathrm{RHT} \\
\text { (randomized) }\end{array}$ & ongoing study \\
\hline
\end{tabular}

RHT = Regional hyperthermia; EIA = etoposide + ifosfamide + adriamycin; ILP = isolated limb perfusion; $\mathrm{WBH}$ = whole-body hyperthermia; 5FU = 5-fluorouracil; VP 16 = etoposide; IFO = ifosfamide; $\mathrm{ADR}=$ adriamcyin = doxorubicin; $\mathrm{CDDP}$ = cisplatin; $\mathrm{CBDCA}$ = carboplatin; Bleo = bleomycin; L-PAM = melphalan; $\mathrm{TNF}=$ tumor necrosis factor- $\alpha$; IFN = interferon- $\gamma ; \mathrm{p}=$ pathohistological; $\mathrm{CR}=$ complete remission; $\mathrm{PR}=$ partial remission; $\mathrm{MR}=$ minor response; $\mathrm{FHR}=$ favorable histological response $>75 \%$; OS $=$ overall survival; $\mathrm{NED}=$ no evidence of disease.

The results so far are encouraging and the study has been extended to patients with a poor response to first-line treatment.

\section{Cervial Cancer}

Recurrences of carcinoma of the uterine cervix develop in almost half of the patients treated for primary invasive cervical carcinoma (Figo stage IIIb/IVa). The majority of these recurrences occur without distant metastases in the pelvis. In this situation, radiotherapeutic or surgical treatment is seldom an option, because most of the patients have already received radiotherapy and very few are suitable for exenterated surgery. In a phase II trial performed within the Amsterdam Gynecologic Oncology Group (AGOG), 23 patients with previously irradiated recurrent carcinoma of the uterine cervix received weekly RHT and cisplatin [42]. The response rate was $52 \%$, median duration of response $9.5+$ months and the 1 -year survival $42 \%$. The overall toxicity was moderate. The fact that $25 \%$ of the responding patients were able to undergo salvage surgery was also encouraging. Therefore, a prospective randomized trial comparing weekly RHT and cisplatin with cisplatin alone has been initiated in cooperation with several European institutions.

\section{Regional Hyperthermia Combined with Radiochemotherapy}

An extension of multimodal therapy concepts incorporating hyperthermia is its combination with radiation and chemotherapy ('triple modality'), which seems to be feasible and effective as tested in several phase I/II trials. A few examples of trimodality studies should be discussed for the tumor entities given in table 3 . 
Table 3. Hyperthermia combined with radiochemotherapy

\begin{tabular}{|c|c|c|c|c|c|c|}
\hline Authors/Reference & Study & Entity & $\begin{array}{l}\text { Number } \\
\text { of patients }\end{array}$ & Hyperthermia & $\begin{array}{l}\text { Radio- } \\
\text { chemotherapy }\end{array}$ & Results \\
\hline $\begin{array}{l}\text { Sugimachi et al., } \\
1992[44]\end{array}$ & phase II/III & $\begin{array}{l}\text { oesophagus carcinoma } \\
\text { (preoperative) }\end{array}$ & 53 & $\begin{array}{l}\text { LHT/Endoradiotherm } \\
13-56 \mathrm{MHz}\end{array}$ & $\begin{array}{l}32 \mathrm{~Gy}+\text { Bleo } \\
(3 \text { weeks) }\end{array}$ & $\begin{array}{l}7 \text { pCR }(27 \%) \text { with RHT }(n=27) \\
2 \text { pCR }(8 \%) \text { without RHT }(n=20)\end{array}$ \\
\hline $\begin{array}{l}\text { Amichetti et al., } \\
1993 \text { [46] }\end{array}$ & phase I/II & $\begin{array}{l}\text { head and neck cancer } \\
(\mathrm{N} 2 / \mathrm{N} 3)\end{array}$ & 18 & $\begin{array}{l}\text { LHT/BSD-MA } 150 \\
280-300 \mathrm{MHz}\end{array}$ & $\begin{array}{l}70 \mathrm{~Gy}+\mathrm{CDDP} \\
(7 \text { weeks })\end{array}$ & $13 \mathrm{CR}+3 \mathrm{PR}(89 \%)$ \\
\hline $\begin{array}{l}\text { Rau et al., } \\
1998 \text { [51] }\end{array}$ & phase II & $\begin{array}{l}\text { rectum carcinoma } \\
\text { (preoperative) }\end{array}$ & 37 & $\begin{array}{l}\text { RHT/BSD } 2000 \\
90 \mathrm{MHz}\end{array}$ & $\begin{array}{l}45 \mathrm{~Gy}+5 \mathrm{FU} / \mathrm{Lv} \\
\text { (4 weeks) }\end{array}$ & $5 \mathrm{pCR}(14 \%)+17 \mathrm{PR}(46 \%)$ \\
\hline $\begin{array}{l}\text { Rau et al., } \\
1998 \text { [51] }\end{array}$ & phase III & $\begin{array}{l}\text { rectum carcinoma } \\
\text { (preoperative) }\end{array}$ & 100 & $\begin{array}{l}\text { RHT/BSD } 2000 \\
90 \mathrm{MHz}\end{array}$ & $\begin{array}{l}45 \mathrm{~Gy}+5 \mathrm{FU} / \mathrm{Lv} \\
(4 \text { weeks }) \pm \mathrm{RHT} \\
\text { (randomized) }\end{array}$ & ongoing study \\
\hline
\end{tabular}

LHT = Local hyperthermia; RHT = regional hyperthermia; Bleo = bleomycin; $\mathrm{CDDP}=$ cisplatin $; 5 \mathrm{FU}=5$-fluorouracil $\mathrm{Lv}=$ leucovorine; $\mathrm{p}=$ pathohistological; $\mathrm{CR}=$ complete remission; $\mathrm{PR}=$ partial remission .

\section{Cancer of the Esophagus}

From 1990 to 9140 patients with locally advanced squamous cell carcinoma of the esopagus were treated with preoperative chemotherapy (bleomycin + cisplatin) either combined with $(\mathrm{n}=20$ patients) or without $(\mathrm{n}=20$ patients) hyperthermia in a prospective trial using a radiofrequency endotract electrode. Objective tumor regression, histopathological effectiveness of the preoperative regimen and improvement of dysphagia were substantially better in the treatment arm combined with hyperthermia [43]. However, the number of pathological CR with no viable cancer cells in the resected specimens were significantly increased when preoperative radiotherapy was also used in addition to thermochemotherapy ('triple modality') as has been shown in previous trials $[44,45]$.

\section{Head and Neck Cancer}

On the basis of the experience in hyperthermia-combined treatment of nodal metastases from head and neck cancer with the addition of either cisplatin or radiotherapy, the Radiotherapy Department of Trento (Italy) performed a phase II study on this disease using trimodal therapy combining hyperthermia, conventionally fractionated radical radiation and weekly low-dose infusion of cisplatin [46]. In 16 out of 18 patients treated in such a way, objective tumor response was $89 \%$ (13 CR / 3 PR) and acute local toxicity was mild. The trimodal therapy deserves further evaluation as a way to enhance the efficacy of radiation and chemotherapy for local control.

\section{Rectal Cancer}

In rectal cancer, resection with negative margins is the major tool for achieving long-term survival. However, in locally advanced tumors (UICC stages II/III) local recurrences after surgery alone have been reported in up to $58 \%$ of patients [47]. For recurrent rectal cancer the prognosis is poor [48]. Efforts to improve the treatment results of locally advanced rectal cancers include preoperative radiotherapy or combined radiochemotherapy. Preoperative radiotherapy for locally advanced rectal carcinomas improved the resectability rate and the duration of local control $[49,50]$. To further intensify

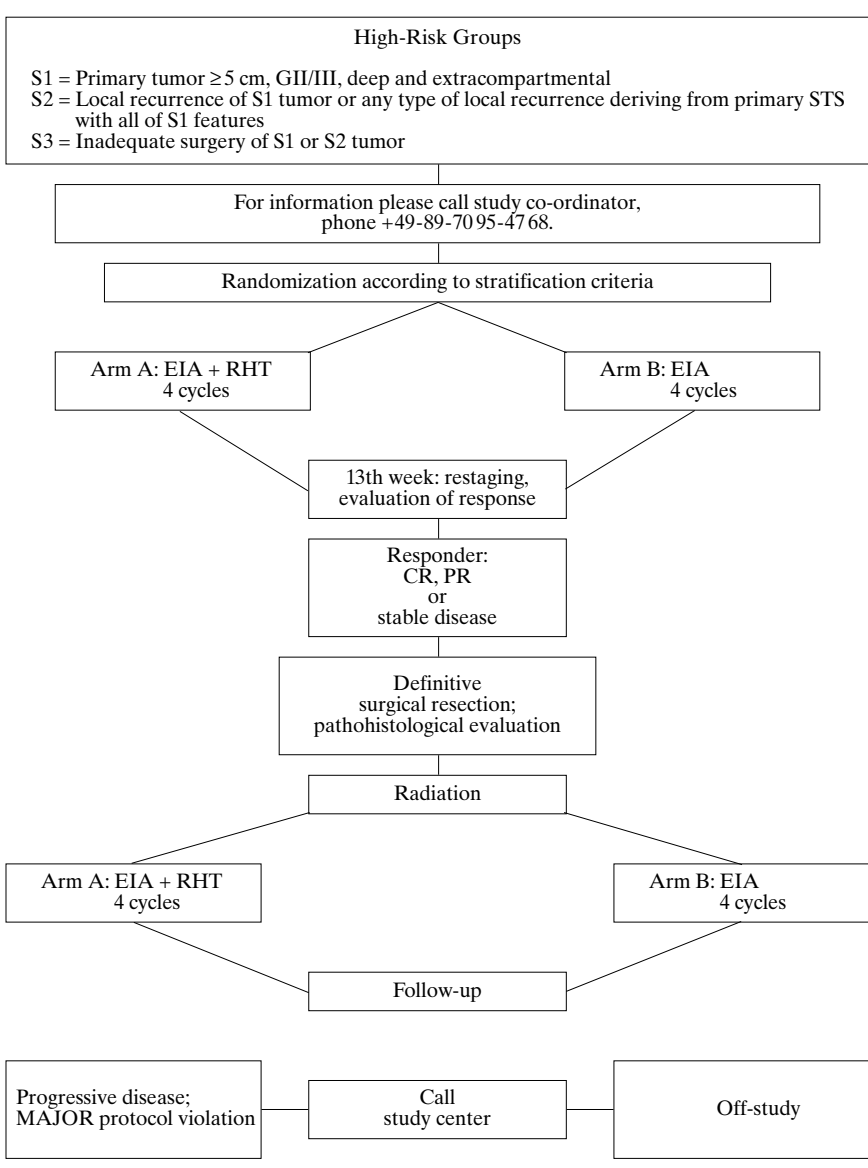

Fig. 1. EORTC 62961/ESHO RHT-95: High-risk soft-tissue sarcoma study; for information please call study co-ordinator, phone +49-89-70 95-4768.

preoperative radiotherapy different regimens of combined chemotherapy and hyperthermia have been tested, showing encouraging results when compared with radiation or chemotherapy alone in historical controls. For example, in a prospective phase II study 37 patients with local advanced rectal 
cancer $\left(\mathrm{T}_{3} / \mathrm{T}_{4}\right)$ were treated with preoperative regional hyperthermia combined with radiochemotherapy [51]. The trimodal treatment was generally well tolerated. The overall resectability rate was $89 \%$. The histopathological report confirmed no evidence of residual tumor in 5 resected specimens ( $5 \mathrm{pCR}$ ) and downstaging $>50 \%$ of the tumor size as documented by CT or endorectal ultrasound in another 17 patients (17 PR). The survival rate after 38 months was $86 \%$ and none of the $31 \%$ of patients with negative margins ( $\mathrm{R} 0$ resection) showed local recurrence, but 5 patients developed distant metastases. The contribution of regional hyperthermia to locoregional tumor control and overall survival within this preoperative setting is now to be proven in an ongoing phase III trial initiated by the same study group.

\section{Conclusion}

The distribution of temperatures (range $40-44{ }^{\circ} \mathrm{C}$ ) achieved in human tumors by regional hyperthermia is heterogeneous mostly dependent on blood supply and tumor-specific parameters. Based upon preclinical investigations, the effects of hyperthermia are mainly due to enhancement of drug efficacy or thermal radiosensitization, and to a lower extent to direct cytotoxicity within areas of tumors heated up to more than $42.5^{\circ} \mathrm{C}$. The technical application of RHT is feasible and effective if combined with chemotherapy or radiochemotherapy, as shown in several clinical studies. Phase II/III trials showed impressive results at clinically relevant temperatures in locally advanced tumors of different entities in terms of objective response rate, local tumor control, and relapse-free survival. Further testing of the potential of regional hyperthermia combined with either of these modalities in prospective randomized trials is warranted.

The clinical experience using WBH is limited to first results of phase I/II studies but needs further evaluation in terms of toxicity and proven efficacy in metastatic disease not responding to first-line chemotherapy.

In general, hyperthermia as an adjunct to conventional treatment strategies can only be recommended in the setting of clinical protocols. The results of prospective trials should answer the question whether hyperthermia becomes standard as part of a multimodal strategy for the treatment of high-risk patients with locally advanced or metastatic tumors.

\section{References}

1 Bauer KD, Henle KJ: Arrhenius analysis of heat survival curves form normal and thermotolerant CHO cells. Radiat Res 1979;78:251-263.

2 Vaupel P: Pathophysiological mechanisms of hyperthermia in cancer therapy; in Gautherie M (ed): Biological Basis of Oncologic Thermotherapy. Berlin, Springer, 1990, pp 74-134.

3 Vaupel PW, Kelleher DK: Metabolic status and reaction to heat of normal and tumor tissue; in Seegenschmiedt MH, Fessenden P, Vernon CC (eds): Thermoradiotherapy and Thermochemotherapy. Berlin, Springer, 1995, pp 157-176.

4 Streffer C: Molecular and cellular mechanisms of hyperthermia; in Seegenschmiedt MH, Fessenden P, Vernon CC (eds): Thermoradiotherapy and Thermochemotherapy. Berlin, Springer, 1995, pp 47-74.

5 Morimoto RA, Sarge KD, Abravaya K: Transcriptional regulation of heat shock genes. A paradigm for inducible genomic responses. J Biol Chem 1992; 267:21987-21990.

6 Hendrick JP, Hartl FU: Molecular chaperone functions of heat-shock proteins. Annu Rev Biochem 1993;62:349-384.

7 Fuller KJ, Issels RD, Slosman DO, Guillet JG, Soussi T, Polla BS: Cancer and the heat shock response. Eur J Cancer 1994;30A:1884-1891.

8 Udono H, Srivastava PK: Heat shock protein 70associated peptides elicit specific cancer immunity. J Exp Med 1993;178:1391-1396.

9 Tamura Y, Peng P, Liu K, Daou M, Srivastava PK: Immunotherapy of tumors with autologous tumorderived heat shock protein preparations. Science 1997:278:117-120.

10 Multhoff G, Botzler C, Jennen L, Schmidt J, Ellwart J, Issels R: Heat shock protein 72 on tumor cells. A recognition structure for NK cells. J Immunol 1997;158:4341-4350.

11 Hahn GM: Hyperthermia and Cancer. New York, NY, Plenum Press, 1982.

12 Steel GG: Terminology in the description of drugradiation interaction. Int J Radiat Oncol Biol Phys 1979;5:1145-1150.
13 Dahl O: Mechanisms of thermal enhancement of chemotherapeutic cytotoxicity; in Urano M, Douple E (eds): Hyperthermia and Oncology. Utrecht, VSP, 1994, vol 4, pp 9-28.

14 Urano M, Douple E: Hyperthermia and Oncology, vol 4. VSP 1994.

15 Haveman J, Rietbroek RC, Gererdink A, van Rijn J, Bakker PJM: Effect of hyperthermia on the cytotoxicity of 2',2'-difluorodeoxycytidine (gemcitabine) in cultured SW1573 cells. Int J Cancer 1995;62: 627-630.

16 Mansouri A, Henle KJ, Benson AM, Moss A, Nagle WA: Characterization of a cisplatinresistant subline of murine RIF-1 cells and reversal of drug resistance by hyperthermia. Cancer Res 1989;49:2674-2678.

17 Towle LR: Hyperthermia and drug resistance; in Urano M, Douple E (eds): Hyperthermia and Oncology. VSP 1994, vol. 4, pp 91-113.

18 Ciocca DR, Fuqua SA, Lock Lim S, Toft DO, Welch WJ, McGuire WL: Response of human breast cancer cells to heat shock and chemotherapeutic drugs. Cancer Res 1992;52:3648-3654.

19 Uckun FM, Mitchell JB, Obuz V, Chandan Langlie M, Min WS, Haissig S, Song CW: Radiation and hea sensitivity of human T-lineage acute lymphoblastic leukemia (ALL) and acute myeloblastic leukemia (AML) clones displaying multidrug resistance (MDR). Int J Radiat Oncol Biol Phys 1992;23: 115-125.

20 Robins HI, Woods PJ, Schmitt CL, Cohen JD: A new technological approach to radiant heat whole body hyperthermia. Cancer Lett 1994;79:137-145.

21 Hand JW, Hind AJ: A review of microwave and RF applicators for localised hyperthermia; in Hand JW, James JR (eds): Physical Techniques in Clinical Hyperthermia. Taunton, GB Research Studies Press 1986;pp 98-148.

22 Feldmann HJ, Molls M, Krümpelmann S, Stuschke M, Sack H: Deep regional hyperthermia: Comparison between the annular phased array and the sigma-60 applicator in the same patients. Int $\mathrm{J}$ Radiat Oncol Biol Phys 1993;26:111-116.
23 Carter DL, MacFall JR, Clegg ST, Wan X, Prescott DM, Charles HC, Samulski TV: Magnetic resonance thermometry during hyperthermia for human highgrade sarcoma. Int $\mathrm{J}$ Radiat Oncol Biol Phys 1998;40:815-822.

24 Oleson JR, Samulski TV, Leopold KA, Scott TC, Dewhirst MW, Dodge RK, George SL: Sensitivity of hyperthermia trial outcomes to temperature and time: Implications for thermal goals of treatment. Int J Radiat Oncol Biol Phys 1993;25:289-297.

25 Dewey WC: Arrhenius relationships from the molecule and cell to the clinic. Int J Hyperthermia 1994;10:457-483.

26 Overgaard J: The current and potential role of hyperthermia in radiotherapy. Int J Radiat Oncol Biol Phys 1989;16:535-549.

27 Overgaard J, Gonzalez Gonzalez D, Hulshof MCCM, Arcangeli G, Dahl O, Mella O, Bentzen SM for the European Society for Hyperthermic Oncology: Randomised trial of hyperthermia as adjuvant to radiotherapy for recurrent or metastatic malignant melanoma. Lancet 1995;345:540-543.

28 Vernon CC, van der Zee J, Liu FF: Radiotherapy with or without hyperthermia in the treatment of superficial localized breast cancer: Results from five randomized controlled trials. Int $\mathrm{J}$ Radiat Oncol Biol Phys 1996;35:731-744.

29 Hiraoka M, Jo S, Akuta K, Nishimura Y, Takahashi M, Abe M: Radiofrequency capacitive hyperthermia for deep-seated tumors. Cancer 1987; 60:128-135.

30 Kakehi M, Ueda K, Mukojima T, Hiraoka M, Seto O, Akanuma A, Nakatsugawa S: Multi-institutional clinical studies on hyperthermia combined with radiotherapy or chemotherapy in advanced cancer of deep-seated organs. Int J Hyperthermia 1990;6: 719-740.

31 Shibamoto Y, Nishimura Y, Abe M: Intraoperative radiotherapy and hyperthermia for unresectable pancreatic cancer. Hepatogastroenterology 1996;46: 326-332. 
32 Issels RD, Prenninger SW, Nagele A, Boehm E, Sauer H, Jauch KW, Denecke H, Berger H, Peter K, Wilmanns W: Ifosfamide plus etoposide combined with regional hyperthermia in patients with locally advanced sarcomas: A phase II study. J Clin Onco 1990;8:1818-1829.

33 Issels RD, Mittermüller I, Gerl A, Simon W, Ortmaier A, Denzlinger C, Sauer H, Wilmanns W: Improvement of local control by regional hyperthermia combined with systemic chemotherapy (ifosfamide plus etoposide) in advanced sarcomas: Updated report on 65 patients. Cancer J Res Clin Oncol 1991;117:141-147.

34 Issels RD, Bosse D, Abdel-Rahman S, Starck M, Panzer M, Jauch KW, Stiegler H, Berger H, Sauer H, Peter K, Wilmanns W: Preoperative systemic etoposide/ifosfamide/doxorubicin chemotherapy combined with regional hyperthermia in high-risk sarcoma: A pilot study. Cancer Chemother Pharmacol 1993;31(suppl 2):S233-S237.

35 Issels RD, Abdel-Rahman S, Salat C, Falk MH, Ochmann O, Wilmanns W: Neoadjuvant chemotherapy combined with regional hyperthermia (RHT) followed by surgery and radiation in primary and recurrent high-risk soft tissue sarcomas (HRSTS) of adults (updated report). J Canc Res Clin Oncol 1998;124(suppl):R105.

36 Wiedemann GJ, d'Oleire F, Knop E, Eleftheriadis S, Bucsky P, Feddersen S, Klouche M, Geisler J, Mentzel M, Schmucker P, Feyerabend T, Weiss C, Wagner T: Ifosfamide and carboplatin combined with $41.8^{\circ} \mathrm{C}$ whole-body hyperthermia in patients with refractory sarcoma and malignant teratoma. Cancer Res 1994;54:5346-5350.

37 Wiedemann GJ, Robins HI, Gutsche S, Mentzel M, Deeken M, Katschinski DM, Eleftheriadis S, Crahe R, Weiss C, Storer B, Wagner T: Ifosfamide, carboplatin, and etoposide (ICE) combined with $41.8^{\circ} \mathrm{C}$ whole-body hyperthermia in patients with refractory sarcoma. Eur J Cancer 1996;32A:888-891.
38 Robins H, Cohen JD, Schmitt CI, Tutsch KD, Feyerabend C, Arzoomanian RZ, d'Oleire F, Longo W, Heiss C, Rushing D, Spriggs D: A phase I clinical study of carboplatin and $41.8^{\circ} \mathrm{C}$ whole body hyper thermia in cancer patients. J Clin Oncol 1993;11: 1787-1794.

39 Robins HI, Rushin D, Kutz M, Tutsch KD, Tiggelaar CL, Paul D, Spriggs D, Kraemer C, Gilis W, Feierabend C, Arzoomanian RZ, Longo W, Albert D, d'Oleire F, Qu RP, Wilding G, Stewart JA: Phase I clinical trial of melphalan and $41.8^{\circ} \mathrm{C}$ whole-body hyperthermia in cancer patients. J Clin Oncol 1997; 15:158-164.

40 Romanowski R, Schött C, Issels R, Klingebiel T, Treuner J, Jürgens H, Göbel U, Goldschmitt-Wuttge B, Feldmann H, Haas R, Havers W: Regionale Hyperthermie mit systemischer Chemotherapie be Kindern und Jugendlichen: Durchführbarkeit un klinische Verläufe bei 34 intensiv vorbehandelten Patienten mit prognostisch ungünstigen Tumor erkrankungen. Klin Pädiatr 1993;205:249-256.

41 Wessalowski R, Kruck H, Pape H, Kahn T, Willer R, Göbel U: Hyperthermia for the treatment of patients with malignant germ cell tumors. A phase I/II study in ten children and adolescents with recurrent or refractory tumors. Cancer 1998;82:793-800.

42 Rietbroek RC, Schilthuis MS, Bakker PJM, van Dijk JDP, Psotma AJ, Gonzalez Gonzalez D, Bakker AJ, van der Velden J, Helmerhorst TJM, Veenhof CHN: Phase II trial of weekly locoregional hyperthermia and cisplatin in patients with a previously irradiated recurrent carcinoma of the uterine cervix. Cancer 1997;79:935-942.

43 Sugimachi K, Kuwano H, Ide H, Toge T, Saku M, Oshiumi Y: Chemotherapy combined with or without hyperthermia for patients with oesophagea carcinoma: A prospective randomized trial. Int J Hyperthermia 1994;10:485-493.
44 Sugimachi K, Kitamura K, Baba K, Ikebe M, Morita M, Matsuda H, Kuwano H: Hyperthermia combined with chemotherapy and irradiation for patients with carcinoma of the oesophagus - A prospective ran domized trial. Int J Hyperthermia 1992;8:289-295.

45 Matsuda H, Baba K, Kitamura K, Toh Y, Ikeda Y, Sugimachi K: Hyperthermo-Chemo-Radiotherapy for patients with early carcinoma of the esophagus Hepatogastroenterology 1993;40:217-221.

46 Amichetti M, Griaff C, Fellin G, Pani G, Bolner A, Maluta S, Valdagni R: Cisplatin, hyperthermia, and radiation (trimodal therapy) in patients with locally advanced head and neck tumors: A phase I-II study. Int J Radiat Oncol Biol Phys 1993;26:801-807.

47 Duncan W, Smith AN, Freedman LF: Clinico-pathological features of prognostic significance in operable rectal cancer in 17 centres in the UK. Br J Surg 1984;50:435-442.

48 Herfarth C, Schlag P, Hohenberger P: Surgical strategies in locoregional recurrences of gastrointestinal carcinoma. World J Surg 1987;11:504-510.

49 Whiting JF, Howes A, Osteen RT: Preoperative irradiation for unresectable carcinoma of the rectum Surg Gynecol Obstet 1993;176:203-207.

50 Mohiuddin M, Marks G, Bannon J: High-dose preoperative radiation and full thickness local excision A new option for selected $\mathrm{T} 3$ distal rectal cancers. Int J Radiat Oncol Biol Phys 1994:30:845-849.

51 Rau B, Wust P, Hohenberger P, Löffel J, Hünerbein M, Below C, Gellermann J, Speidel A, Vogl T, Riess H, Felix R, Schlag PM: Preoperative hyperthermia combined with radiochemotherapy in locally advanced rectal cancer. A phase II clinical trial. Ann Surg 1998;227:380-389.

52 Eggermont AM, Schraffordt Koops H, Lienard D, Kroon B, van Geel AN, Hoekstra HJ, Lejeune F: Isolated limb perfusion with high-dose tumor necrosis factor- $\alpha$ in combination with interferon- $\gamma$ and melphalan for nonresectable extremity soft tissue sarcomas: A multicenter trial. J Clin Oncol 1996;14: 2653-2665. 